\title{
The Imperative Of Basic Tax Education For Citizens
}

Gladson Nwanna, Morgan State University, USA

Darlington Richards, Morgan State University, USA

\begin{abstract}
The role and impact of taxes in the lives of Americans makes basic tax education an imperative for all Americans. Not only will that knowledge be valuable to the taxpayer, it will also be valuable to the Government that imposes a variety of taxes. Specifically, it is our position that the lack of basic understanding of taxes is unwarranted, long overdue and importantly could be costing the taxpayers hundreds of millions of dollars. In this paper, we focus on the personal income tax because it is one of the most recognizable of the taxes and because it does account for a significant amount paid by Americans. While we wholeheartedly agree that basic knowledge of all other types of taxes will equally be valuable, the income tax, we believe, is a good starting point in light of its unique effect on the majority of Americans.
\end{abstract}

Keywords: Tax Education, Individual Income Tax, Tax Deductions, Tax Evasion, Tax Compliance, IRS, Tax preparers, Taxes, Tax Policies, Tax Gap

\section{INTRODUCTION}

$\mathrm{n}$ the U.S., citizens are subject to a variety of taxes. The most popular include income taxes (personal \& corporate), sales and excise taxes, payroll taxes and unemployment taxes. Several of the taxes are levied by various levels of government, including federal, state and local levels. These taxes impact various categories or segments of the population and impact on them differently, some progressively, others regressively and selectively. Amongst these range of taxes, the Federal Income Tax, in general, and Federal personal income tax, in particular, are most recognizable and most often talked about by Americans. It is also one of major concern to the Internal Revenue Service (IRS), which is the Federal government's enforcement arm. Incidentally, it is the lack of basic understanding of taxes, in particular, among other factors, that appears in our judgment to be lacking or deficient and in urgent need. This lack of basic knowledge may result from several reasons, the most important in our opinion, is being the apparent lack of a systematic and comprehensive approach to the subject by the government, and the lack of adequate appreciation of the importance by citizens and, by default, the lack of urgency on the part of government and policy makers to address or tackle the issue in a manner consistent with the importance of tax education.

\section{CONSTITUENTS}

Tax education of Americans, as proposed in this paper, will involve the participation of a number of constituent groups. This will include legislators, the IRS, tax preparers, tax professional associations, schools, churches and taxpayer advocacy groups, such as the Office of the National Taxpayer Advocate. Success will depend significantly on the availability of resources, financial in particular, and funding of the IRS and the various constituent groups who will be involved in the process.

\section{THE ROLE OF LEGISLATORS}

To ensure success, there will be need for additional specific, if not mandatory, legislations at all levels of government, and the Federal government, in particular, that will create the enabling environment and support for the initiative. 


\section{THE ROLE OF THE IRS}

The IRS, as the enforcement arm of the Federal Government on tax matters, will certainly be involved. There is no doubt the IRS has been active in disseminating information about taxes to the general population using a variety of outlets, including publications, both online and in print form. There have also been additional services available at some of their field offices, as well as by phone, to assist taxpayers. While these outlets are helpful to taxpayers with tax-related questions, they are not particularly geared toward the type of education this paper is focused upon, nor are they robust and adequate in addressing the range of issues and topics that the proposed basic tax education calls for. Similarly, we acknowledge the existence of the IRS website, where the agency has provided model lesson plans (entitled "Understanding Taxes") that can be readily utilized to achieve a good amount of the education this paper proposes. The reality, however, is that visitors to the IRS website are generally unaware of its existence and/or will have difficulties accessing it. The internet-based lesson plans and other tax-related information disseminated by the IRS of course assumes that taxpayers own computers, have access to computers and the internet, and/or are computer and internet savvy. In essence, it ignores the large number of taxpayers and prospective taxpayers who do not have access to the internet or who many not have the relevant knowledge base to benefit from it in its present form/format. Furthermore, we have not found any additional efforts on the part of the IRS to market the lesson plan site to the general public in a manner consistent with the type of tax education we are proposing. IRS' involvement in tax education, as it presently exists, appears primarily and largely focused on tax preparation and filing assistance, tax collection, enforcement and compliance matters than a more robust, comprehensive, citizen-wide tax education that has the potential for a better and more successful and effective tax administration. Although the IRS, in its dealings with Congress, continues to emphasize the lack of sufficient resources to carry out its mandate, it is not clear if provided more resources will employ a robust and comprehensive approach that will significantly include the broad-based tax education of its citizens that we suggest.

\section{THE ROLE OF TAX PREPARERS}

Tax preparers have long existed to assist taxpayers prepare and file their taxes. Unfortunately, they have not fared well as an educational tool; and while a good number of them can be utilized to provide tax-related information/education, it has also become clear to the IRS and some members of the informed public that many in their present form do not possess the relevant tax-related knowledge to be of great use to the proposed initiative. The proposed plan, by the IRS to require a certain minimum amount of demonstrable education or tax knowledge by paid tax preparers through some type of qualifying education, will at least address the problem of unqualified tax preparers ${ }^{i}$. On the assumption that the IRS will follow through with the testing and qualifying of certain categories of tax preparers, they will certainly be useful in the education of American taxpayers. In this capacity, the role of tax preparers may have to be expanded to include some minimum education of their clients. A large majority of tax preparers, understandably, spend little or no additional time educating or providing tax information to their clients. Instead, much time is spent only trying to collect as much relevant information to enable them to prepare and file their taxes or amend their client's taxes. Less time is devoted to tax education or tax planning for their clients.

\section{THE ROLE OF TAX PROFESSIONALS AND PROFESSIONAL TAX ORGANIZATIONS}

Tax professionals and professional tax organizations will play an integral part in any scheme or strategy aimed at providing basic tax education to citizens. For tax professionals, including CPAs and IRS enrolled agents whose typical activities bring them in contact with millions of taxpayers and prospective taxpayers, the breadth and depth of accounting and tax knowledge of these individuals, and the regularity of their contacts, provide an avenue unmatched by the other groups essential to the success of a citizen tax education. The same can be said about the numerous professional tax and accounting organizations. These organizations, including the National Association of Tax Professionals (NATP), the American Institute of Certified Public Accounts (AICPA), and their regional groups, will be instrumental in the promotion and educational process as well as in the development of relevant instruments. These organizations also have the ability to provide appropriate incentives to their members to participate in the proposed endeavor. 


\section{THE ROLE OF SCHOOLS}

Schools have traditionally served as avenues for the dissemination of knowledge and/or information and can be utilized meaningfully to provide formal tax education/information to the public. A well structured, ageappropriate curriculum and lesson plans on taxes initiated or adopted at schools (all levels, from elementary to college, from private to public schools, from community to local schools) will be useful. Just as students are provided basic education on American History and Civic Education, basic tax education can be implemented along similar lines. Not only will the benefits be life-long, they will certainly be a win-win for all affected parties. Students will grow with a better knowledge of taxes and the importance of tax planning, but also with a better understanding and appreciation of their constitutional obligations with regard to taxes. They will grow in understanding the role of taxes, why governments levy and collect taxes, the services provided them by government, how to legally minimize their tax burden, and importantly, the futility of tax evasion. Without much doubt, we believe tax enlightened students will become better taxpayers, engage in better tax planning, minimize the tendency to avoid or evade taxes, and, by so doing, reduce the huge cost spent by the IRS in tax enforcement and compliance ${ }^{\text {ii }}$.

\section{THE ROLE OF CHURCH, COMMUNITY GROUPS AND NON-GOVERNMENTAL ORGANIZATIONS (NGOS)}

Like schools, churches, community groups, and NGOs can be useful in providing not only the awareness, but basic tax education to citizen groups. In a broader framework of what we envisioned in advocating basic tax education, all segments of society, including churches, community groups, and NGOs, will have to be engaged and involved. The relationship some of these segments of society have already built, and continue to build, with their members, their proximity to citizen taxpayers and prospective taxpayers, and their role as potential sources of information of various kinds (social, economic, political and spiritual), will certainly make them an integral and important part of the tax education effort. Success in enlisting the support and participation of churches, community groups, and NGOs for the proposed tax education initiative will require government assistance and support by way of providing an enabling environment, including financial resources.

\section{THE ROLE OF POLICYMAKERS}

Tax education and the perceived advantages and benefits to the various consitutencies addressed in this paper, we suggest, should be equally as importance to the government as to policymakers, at least to the extent that they must, and continue to, embrace and tackle fiscal policies and the related questions of revenue, budget deficits, and government spending. The outcome of a tax enlightened and educated citizenry will undoubtedly affect government's success with revenue and revenue collection and will determine, in large part, the success - or the lack of it - in carrying out the government's planned economic, as well as social, objectives/agenda. In order for the idea proposed in this paper to work, and to work correctly, various elements of society, including policy makers, will have to be involved, particularly in creating the enabling environment as well as supporting the enabling policies, and initiatives, including appropriate legislations and technical infrastructure.

\section{THE ROLE OF THE OFFICE OF TAXPAYER ADVOCATE ${ }^{i i i}$ AND LOCAL ADVOCACY GROUPS}

The Office of Taxpayer Advocate (OTA) and local advocacy groups have, and continue to, play significant roles in protecting and advancing the interest and welfare of taxpayers. The regular testimony of OTA various government committees and sub-committees, on behalf of taxpayers, is commendable and so are their field and telephone operations aimed at assisting taxpayers in navigating the often daunting, if not confusing, IRS web. In the role of these advocacy groups a constant has not only been their request for a better and fairer treatment of taxpayers, but also for improved taxpayer services (especially outreach and education) ${ }^{\mathrm{iv}}$ which includes providing taxpayers with timely and adequate information. In their present mission and/ or mandate, along with their existing infrastructure and reach, the Office of the Taxpayer Advocate and various tax advocacy groups will be an asset in the efforts to provide basic tax education to the masses. Not only will they be a good fit, the legal mandate for the OTA, in particular, could be utilized to advance the proposed tax education. 


\section{WHAT IS LOST BY TAXPAYERS?}

Although we could not find any empirical research documenting the cost or loss to taxpayers resulting from their lack of basic knowledge on taxes, casual empiricism, inferred through indirect measures, will show the amount to be in the millions of dollars every year. This does not include any non-quantifiable secondary or tertiary value of such education to the taxpayer. On the surface, we dare to say that a large number of citizen taxpayers will fail to fully appreciate the importance and role of tax revenue to the government. That many taxpayers are generally tax averse when it comes to paying taxes could be, in part, the result of their lack of understanding and appreciation of the role of government, the range of services provided by the government, and the fact that these services have to be paid for through taxes and other revenue sources. These typically less educated citizens often have little or no knowledge regarding the creation of money, except for their narrow definition of government printing money from paper. Not only are some of these citizen taxpayers antagonistic to the idea of taxes, but they often manifest and direct that disgust and associated negative feelings to the agency of the government (IRS) charged with collecting the taxes and enforcing the law. The counter-productive beliefs of these segments of the population regarding taxes and the IRS have often endeared them to the rumors and doctrines of radicals and groups inimical and opposed to governments' rights to impose and collect taxes from its citizens. It would appear that these citizens are usually oblivious to the host of services provided by the government - services that ironically are vital for the sustenance, good health and comparatively higher standard of living they enjoy or aspire to enjoy.

The lack of basic tax education, and the related lack of tax planning, can be attributed to millions of taxpayer citizens failing to take advantage of various credits, deductions and legal loopholes that they can fully take advantage of. IRS's meager/half-hearted effort to promote the availability of (e.g. the earned income credit) is a good example of the void in knowledge that we believe is costing taxpayers millions of dollars. Similarly, the same can be said of numerous deductions, some general and others job-specific, that these taxpayers qualify to claim but are not claiming, deduction and credits that some of the taxpayers fail to mention or remind their tax preparers about, believing instead that their tax preparers will search and apply them. Unfortunately, many so-called tax preparers are not adequately knowledgeable themselves and/or do not devote the time to become proficient at the services they provide. As a result of the limited knowledge, these incompetent taxpayers will fail to fully research and apply legal tax loopholes to reduce their client's tax burden; i.e., tax loopholes that usually appear to be in the domain of a minority - the wealthy and tax-educated citizens. We note, in the same vein, the millions of tax refunds and potential refunds that are unclaimed by hundreds of thousands of taxpayers who fail to file their taxes, are afraid to file their taxes, in part due to their lack of basic tax knowledge or tax education, as we advocate in this paper. That a large number of taxpayers equate filing their annual tax returns to paying tax and/or giving money to "Uncle Sam" is equally as erroneous and knowledge-deficient as a similarly large number who ignorantly and naively equate tax filing to getting back "all monies" that were deducted out of their paychecks. Basic tax education will, in our opinion, be most beneficial to these taxpayers or citizens.

\section{THE ADVANTAGES TO TAXPAYERS}

The advantages of basic tax education/knowledge, we believe, are real and plentiful, both direct and indirect. Although the exact dollar amount of the benefits may be hard to estimate, several taxpayers will benefit in the following ways:

- $\quad$ Financially, taxpayers deserving of tax refunds and who otherwise would not have received one, will find the added awareness and knowledge useful. There are also savings from avoiding potential penalties from the IRS for none compliance, particularly in the case of misinformed and less informed citizens who ordinarily would not file their taxes and/or pay their 'fair share' as required by law.

- $\quad$ Basic tax education, if properly executed, we believe, will increase not only the number of citizens who are required to file personal income taxes and are currently not doing so, but also will increase the overall compliance rate - a goal and task of great importance to the IRS. It has the potential for creating more law abiding, empowered, taxpaying citizens. 
- Equally as important as the financial rewards that may result from tax education is the increased tax knowledge and sense of awareness of citizen taxpayers, benefits which undoubtedly will instill, if not equip, them with tools and knowledge to demand for better accountability from the government and appreciation of the role of their government. Tax informed taxpayers will be better positioned to understand their tax returns as well as engage and/or challenge incompetent tax preparers.

\section{THE ADVANTAGES TO THE GOVERNMENT}

The advantages to the government of a basic tax education for its citizens can be, in part, inferred from the discussions in the preceding paragraphs addressing what is lost to taxpayers, the advantages to the taxpayers, and what is lost to the government.

The advantages to the government, more specifically, will include: better (tax) informed and taxknowledgeable citizens, the potential for increased compliance by citizens, the potential for reducing the rate of noncompliance and associated cost of effecting compliance, increased support, if not better understanding and/or appreciation, of government initiatives and, above all, better chances of tax collection and increased tax revenue. With the tax gap presently estimated at $\$ 345$ billion $^{\mathrm{v}}$, tax education has the potential of reducing that gap significantly, including the growing cost of enforcement by the IRS.

\section{CONCLUSION}

Basic tax education for US taxpayers and prospective taxpayers is as much an urgent call and a necessary task, we believe, as it is equally urgent and necessary on the part of governments that levy a variety of taxes as a major source of revenue. It is both our contention and proposal that it is a matter of "national security" considering that an enlightened and tax-knowledgeable citizenry will be comparatively less averse to taxes, income tax in particular, less hostile to the IRS, less rebellious or militant on tax matters, and more tax compliant. This will, in turn, provide a less costly means for government to raise needed tax revenues. To achieve the goal advanced in this paper will involve participation at every level and with various segments of the society, including the government and the IRS, in particular, the educational institutions, community groups, non-profit organizations, tax preparers, professional tax/accounting organizations, legislators, and policymakers alike. Basic tax education should be accorded a similar level of importance and urgency as history, civic studies, and the three R's, as well as an integral part of financial education. Similarly, tax planning should equally be stressed as an important and integral part of financial planning. It is within this scope of recognition and implementation of a coherent and well defined and planned tax education and associated curriculum that the true benefits we envision will be realized. The importance and technical nature of the subject matter and the complexity of taxes is not one that can be approached haphazardly or piecemeal, but one that has to be approached in a systematic, comprehensive and well-articulated manner with age appropriate messages and lesson plans. It is our strong belief that the benefits to both the government and the taxpayers will be well worth the investment; besides, we believe it will also make better and well-informed and empowered citizens. The common adage that "Knowledge is Power" is fitting and very well applies in what we are advocating. The fact that the IRS acknowledges in its 2005-2009 Strategic Plan" that "lack of Knowledge" is part of the reason "why taxpayers are noncompliant with their tax obligations" is the more reason that tax education for all citizens is urgent, necessary, and a sound investment.

\section{AUTHOR INFORMATION}

Dr. Gladson I. Nwanna is a professor in the Accounting \& Finance Department at Earl Graves School of Business and Management, Morgan State University, Baltimore, Maryland, USA.

Dr. Darlington Richards is a professor in the Business Administration Department at Earl Graves School of Business, Morgan State University, Baltimore, Maryland, USA. 


\section{ENDNOTES}

i "Regulation of Federal Taxpayers", A presentation made to the US House of Representatives Committee on Ways And Means Subcommittee on Oversight by Nina E. Olson of the Office of National Taxpayer Advocate. July 20, 2005.

ii In the Fiscal Year 2005 IRS Budget, over \$6.3 billion dollars was appropriated for Enforcement.

iii http://www.irs.gov/pub/irs-utl/evolution_of the_office_of the taxpayer_advocate.pdf

iv The IRS and the Tax Gap", A presentation made to the Committee on the Budget, U.S. House of Representatives by Nina E. Olson of the Office of National taxpayer Advocate. February 16, 2007, p. 3.

v http://www.irs.gov/newsroom/article/0,,id=154496,00.html

vi Cited in a presentation made by Nina E. Olson of the Office of National Taxpayer Advocate before the Committee on Ways And Means, Committee on Appropriations, Committee on Government Reform, of House of Representatives; Committee on Finance, Committee on Appropriations; Committee on Homeland Security and Government Affairs, United State Senate for the Joint Review of the "Strategic Plans and Budget of the Internal Revenue Service", May 19,2005 